\title{
1. Getting beyond slow boil in the South China Sea
}

\section{Andrew Scobell}

The South China Sea has become one of the most important bodies of water in the world in economic and strategic terms. ${ }^{1}$ About one-half of the world's maritime trade measured by merchant fleet tonnage passes through it each year, making its sea lanes among the most heavily traveled in the world. Their disruption by pirates or warring powers would affect the economic security of all the surrounding countries as well as that of others, including Taiwan, Korea, Japan, Australia, and their protector, the United States. With modern fishing technology, the sea yields over ten million tons of fish per year, and the technology now exists to begin to exploit the potentially vast, and still unmeasured, reserves of oil and gas that lie under its seabed.

A recent book dubbed the South China Sea "Asia's Cauldron."2 Does such a label seem apt or excessively provocative? Since at least 2010, the South China Sea has appeared to be on a "slow boil." Tensions seem to simmer and fluctuate over time. Occasionally, they bubble up, creating turbulent waters in the process. But this turbulence eventually subsides, and the sea returns to a gentle bubble for a while. Then, the cycle repeats itself.

How serious are the tensions over this body of water? Does the South China Sea warrant the term "flashpoint" or "hot spot"? The tensions seem serious, but the dangers of escalation appear less severe than those of other flashpoints in the Asia-Pacific, such as the Korean Peninsula, the Taiwan Strait, and the Vale of Kashmir. Like the South China Sea, these geographic locations exhibit chronic tensions, but they seem qualitatively distinct in at least one respect - each faces acute frictions that could plausibly escalate into major military conflicts. ${ }^{3}$ Indeed, Korea, Taiwan, and Kashmir have each produced serial crises and at least one major military conflict over the past sixty-odd years. In contrast, the South China Sea has merely experienced minor naval clashes and small-scale military confrontations over just the past forty-some years, and none of these incidents threatened to escalate into a larger or wider conflict. 
So why is the South China Sea different from these other regional flashpoints? The chronic but less acute nature of this Southeast Asian hot spot is partly a result of the nature of the flashpoint - exclusively maritime, and somewhat removed from population centers - and partly because, at least until very recently, none of the disputants has possessed air and naval assets capable of producing horizontal or vertical escalation. This latter condition is starting to change as both the Asia-Pacific and Southeast Asia are experiencing incipient arms races, especially where navies are concerned. ${ }^{4}$ According to the International Institute for Strategic Studies, "Asian defense spending ... [is] increas[ing] strongly." ${ }^{5}$ Moreover, technological advances in weaponry, communications, and information mean that distances have shrunk. Developments such as ballistic missiles and satellite imagery have transformed once distant areas into accessible and visible locations. ${ }^{6}$

\section{HISTORY}

Starting in the 1970s, the surrounding countries gained the naval capabilities to fully chart the region and stake their claims as well as the commercial capability to exploit them. ${ }^{7}$ Advancing gradually through the region, the Chinese, Vietnamese, and Malaysian navies surveyed the waters; located hundreds of small islands, reefs, and other land formations; and installed observation platforms, meteorological stations, and small harbors. (The Philippine and Brunei navies were not equipped to compete with the others.) Fisheries fleets moved farther from shore, and surrounding countries began to lease offshore oil and gas fields to international companies. All the surrounding countries claimed various territorial rights to portions of the Sea and clusters of its islands. International law gives every country around an international body of water some rights. These range from excluding other countries' ships except for "innocent passage" (usually within 12 nautical miles of the relevant land body) to the right to exclusive economic exploitation (usually within 200 nautical miles). When countries are close together, as is the case with nations surrounding the South China Sea, the claims overlap. The legal principles give outsized importance to small islands, reefs, and atolls because their owners can claim special rights in large areas of sea around them. There are many different bases for plausible claims to islands, including first discovery, historical possession, and geographical connection to the home country's continental shelf. Where countries are close together around a body of water, it is not unusual for their claims over islands to overlap.

Such is the case in the South China Sea. The Sea contains four main clusters of outcroppings widely scattered across its surface. The Paracel Islands, 
located in the northern part of the South China Sea about equidistant from Vietnam and China, consist of over thirty small islands and other land formations scattered across some 6,000 square miles of water. The Spratly Islands, located farther south some 300 miles from the coast of Vietnam and 700 miles from China's Hainan Island, consist of over a hundred small bits of land spread over about 160,000 square miles of water. The Pratas Islands, in the northeast part of the South China Sea not far from Hong Kong, consist of three islands. The Macclesfield Bank is a group of rocks close to the Philippines. (The Sea also contains a number of other land features in addition to these.) Taken as a whole, these formations include only about ten square miles of land surface above the water. Few are habitable without outside supplies of food and water. But if countries use them as the basis for claiming their 200-nautical mile exclusive economic zones, then they potentially provide title to large expanses of the South China Sea.

\section{THE SITUATION IN THE LATE 2010s}

What is the situation in the late 2010s? There are several key ways to characterize the South China Sea flashpoint. First of all, the South China Sea continues to be a chronic hotspot, albeit one that may very possibly become more acute. The disputes between rival claimants and interested outside parties have simmered for decades and appear likely to remain unresolved for the foreseeable future. Furthermore, at the same time as the stakes involved appear to be rising, multiple claimants have significantly increased their military capabilities. The role of individual leaders cannot be ignored - prominent national figures can exacerbate or ameliorate tensions. For example, President Roderigo Duterte of the Philippines, elected to office in 2016, could through his blunt rhetoric and unconventional policies either contribute to an escalation or de-escalation of the South China Sea flashpoint.

Second, the disputes are multilateral. That is, they involve more than two states as well as a number of third-party actors. This makes the disputes more complicated, as bilateral agreements cannot produce a comprehensive and sustainable resolution.

Third, the disputes are multifaceted in scope and involve not only territory (land or sea), but also ownership of and access to a variety of resources. Most notable are the exclusive economic zones (EEZs) claimed by some countries based upon their claims to islands, reefs and atolls in the South China Sea.

Fourth, these disputes are multidimensional. In other words, the disputes encompass multiple dimensions - not just legal issues, but military, 
law enforcement, diplomatic, and economic ones as well. The legal dimension was highlighted by the United Nations Convention on the Law of the Sea (UNCLOS) Annex VII Arbitral Tribunal ruling issued in July $2016 .^{8}$ While some parties to the dispute, notably China, would prefer to ignore this decision, the multidimensional reality means they cannot. Thus, despite Beijing's insistence that it does not recognize the ruling, China has nevertheless felt it necessary to respond in other ways, including reaching out bilaterally to the Philippines, and re-energizing a multilateral initiative to devise a code of conduct for the South China Sea.

\section{THE STABILITY-INSTABILITY PARADOX IN THE SOUTH CHINA SEA}

There are certain common views discernible among the disputing parties. These include a common desire to avoid a major military conflict over the South China Sea. At the same time, most countries also tend to assume that the current tensions and possible future confrontations or crises have very low probabilities of escalation. While the former view is constructive, the latter is not. If disputants believe the escalation potential is very low or even non-existent, they may engage in excessively risky or provocative behavior.

Of course the two viewpoints are related - the latter is predicated upon the former. It might be useful to conceive of these two views as constituting a non-nuclear variant of the stability-instability paradox. In the case of the South China Sea, regular confrontations between coastguard or naval vessels and fishing boats from different states and infrequent but periodic small-scale skirmishes between different states' coastguard and naval ships produce a slow boil, which generates a heated atmosphere that is not conducive to dialogue or cooperation - not to mention negotiating a resolution of the dispute.

A common view among claimants other than China is that Beijing has a different timeline and a different strategy from the others. In the view of many countries, China is perceived to be:

- Unwilling to compromise

- Growing stronger

- Becoming more assertive

- Having time on its side.

Almost certainly, China has been more active and definitely has displayed greater ambition that the other South China Sea claimants. 
China claims a very large number of the formations in the South China Sea. ${ }^{9}$ China's claims overlap in various ways with those of Vietnam (whose claims include the entirety of the Paracel and Spratly islands and are the largest after China's) and of Malaysia, the Philippines, and Brunei. If China were to make good on all its claims and enforce a 200-mile EEZ around them, it would own the whole Sea except for the small zones just off the coasts of the surrounding states. Indeed, such a claim to the entire Sea was illustrated by a famous map originally published by the Nationalist government in 1947 and republished by the PRC in 1992, called the "ninedash line map" because it showed Chinese claims in a sweeping arc of nine long dashes around the Sea's perimeter. In 1993, China also published a map seeming to show a claim to areas close to the Natuna Islands in the far south of the South China Sea, which are held by Indonesia, but this claim has not been clarified or repeated. However, in subsequent communications, Beijing has sought to reassure Jakarta that China does not claim the Natunas and, as a consequence, this appears to be virtually a non-issue in bilateral relations. ${ }^{10}$

Starting in the 1970s, China has pushed steadily forward to consolidate its position with a mix of military, diplomatic, and economic tools, while trying not to frighten its rivals into a united front against it. In 1974, Chinese naval forces clashed with the forces of the Republic of Vietnam (South Vietnam) in the Paracel Islands. Beijing took advantage of the waning months of the Saigon regime to strengthen its hold on these disputed features. The larger PLA Navy (PLAN) flotilla bested the fourvessel Vietnamese force, and China seized the Paracels' western group, taking control of the entire archipelago. In 1988, PLAN forces fought with forces of the Socialist Republic of Vietnam in the Spratly Islands - a skirmish which escalated from a struggle between rival landing parties on a reef. The PLAN won the main battle, which took place at Johnson Reef, and China went on to occupy six nearby reefs claimed by Vietnam and the Philippines. In 1992, China granted a concession to the Crestone Energy Corporation for work in the southwest corner of the South China Sea, adjacent to the Spratlys. In 1995, the Philippines discovered that the Chinese Navy had moved onto the Mischief Reef, a formation in the Spratly group close to the Philippines, and had built a permanent structure there that was manned with PLAN sailors who drove Filipino fishermen away. In 1997, a state-owned Chinese energy company drilled for gas in contested waters off the coast of Vietnam. Punctuating these events were a series of clashes between Chinese naval vessels and fishing boats from various countries that were encountered in waters China claimed. This pattern of clashes and harassment by Chinese maritime security forces continued into the second decade of the twenty-first century. Beijing reinforced its 
claims in 1988 by upgrading Hainan to provincial status and assigning each of the islets, reefs, and atolls that it claimed in the South China Sea a place in Hainan's administrative hierarchy. In 1992, the National People's Congress Standing Committee adopted the Law of the People's Republic of China on Territorial Waters and Contiguous Territories, which asserted China's claims to extensive areas of the South China Sea. ${ }^{11}$

These actions exacerbated longstanding suspicions of China around the region. For many of the states of Southeast Asia, China had a legacy of fomenting revolution. Under Mao, China had supported communist insurgencies verbally and sometimes materially in the Philippines, Indonesia, Singapore, Malaysia, Thailand, and Myanmar. Beijing cut its ties with these insurgencies starting in the late 1970s. In some cases, the insurgencies were heavily ethnic Chinese in composition. Even though the PRC had ceased to claim the sizable ethnic Chinese populations in these countries as citizens starting in 1954, it still called them "overseas Chinese" and gave them the right to return to China to study and settle. Alarm about Beijing's readiness to use force to achieve policy goals has endured because of Chinese actions. As recently as 1979, China fought a war with Vietnam partly over Hanoi's closer alignment with Moscow, partly over territorial disputes, and partly over the treatment of the ethnic Chinese there. The 1995-96 Taiwan Strait Crisis created new fears that China was becoming assertive and threatening. While China was successful in improving its image in Southeast Asia with a "charm offensive" between the 1990s and 2000s, by 2010, Beijing's assertive steps to exercise sovereignty claims in the South China Sea had resurrected fears in the region that China was reverting to the use of military force and coercion.

Beijing recognized that it had an image problem and sought to address it. In 1997, Foreign Minister Qian Qichen gave the first high-level exposition of the "New Security Concept" at the annual meeting of the ASEAN Regional Forum held in Malaysia. The concept echoed the Five Principles of Peaceful Coexistence, which Zhou Enlai had presented at the 1955 non-aligned summit in Bandung. China's response to the 1997-98 Asian Financial Crisis also helped soften its image: Beijing played a stabilizing role by not devaluing its currency and by offering low interest loans to countries in the region. In 2002, Beijing signed the Declaration on the Conduct of Parties in the South China Sea, which had been drafted by the Association of Southeast Asian Nations partly at the instigation of Vietnam. The parties pledged to peacefully resolve sovereignty disputes, but the declaration contained no specific provisions to resolve them. In 2004-05, the China National Offshore Oil Corporation (CNOOC) joined with the Philippine and Vietnamese national oil companies in a Joint Marine Seismic Undertaking (JMSU) to explore portions of the South 
China Sea seabed for energy resources. In 2011, under U.S. prodding, China agreed to push forward with implementing confidence building measures with ASEAN states in the South China Sea.

Through none of these actions, however, did Beijing concede any territorial claims. It avoided legalistic debates that would have required it to specify the historical and legal basis of its claims in detail. Instead, Beijing pushed forward to consolidate its physical presence. Incidents continued, with the Chinese navy firing on fishing boats, harassing naval vessels of other Southeast Asian countries, and warning oil companies not to explore for oil in concessions granted by Vietnam. In the early 2000s, Chinese air and naval forces began to challenge U.S. air and sea craft on surveillance and monitoring missions just outside the 12-mile territorial limit. The U.S. considered these missions legitimate in international waters and airspace, while China viewed them as provocative. In 2001, a Chinese fighter plane shadowing an American EP-3 surveillance aircraft about 70 miles off the Chinese coast collided with it, causing the damaged American plane to land in Hainan and triggering a diplomatic standoff that lasted several weeks; meanwhile, the Chinese fighter pilot, who died, was lionized in the Chinese official press. In another incident in 2009, Chinese naval vessels surrounded the USNS Impeccable when it was operating in waters about 75 miles south of Hainan, making navigation dangerous. More recently, in December 2016, a PLA naval vessel seized a U.S. military underwater drone some 50 miles off the coast of the Philippines (the device was later returned). China's apparent goal was the same in all these episodes: to push back the scope and range of U.S. military activities in the South China Sea. In 2010, some Chinese leaders reportedly informed American officials that the South China Sea was a "core interest," although the claim was not further articulated. Asian neighbors viewed such actions as part of a larger pattern of Chinese assertiveness around the region, symbolized by China's overall naval buildup and unprecedented coastguard expansion. ${ }^{12}$

China's activism in the South China Sea has continued more recently. In 2012, China displayed its maritime muscle against the Philippines near the Scarborough Shoal. In May 2014, China's CNOOC installed an oil rig inside the EEZ claimed by Vietnam without any prior notification or explanation. The rig was withdrawn two months later, but Beijing had successfully signaled its resolve.

As a result of these activities, other states have concluded that Beijing is engaged in a long game where the South China Sea is concerned. Despite China's expanding grey hull and white hull presence, there is no near-term prospect that it can achieve its maximum goal of controlling all the island groups and their EEZs without resorting to outright military action. Instead, Beijing seems to be focused on a long term strategy (see below). 
In their attempts to counter China's "long game," the other, smaller disputants have looked to outside powers - particularly the United States and Japan-to balance against China's daunting power.

\section{SLOW INTENSITY CONFLICT IN THE SOUTH CHINA SEA}

This author has described China's strategy in the South China Sea as one of "slow intensity conflict (or "SLIC")."13 SLIC is a stealth-like strategy to lull the other claimants into believing that no conflict exists. SLIC - unlike low intensity conflict or LIC - involves war between the regular armed forces of states but tends to entail primarily minor and infrequent skirmishes between small units. It is a protracted struggle waged with all the instruments of national power-not just military, but also diplomatic, economic, and informational power. SLIC makes it difficult for other claimants to keep attention focused on the issue and coordinate with neighbors.

But SLIC might also be used to characterize not only the strategies of a number of disputants, but the general "slow boil" phenomenon that the South China Sea has witnessed over the past two decades as well. Thus, SLIC is chronic. Moreover, while it may be unlikely to escalate, SLIC nevertheless tends to undermine the prospects for meaningful dialogue and negotiation.

\section{ROLE OF THIRD PARTIES}

China appears convinced that rising tensions in the South China Sea are the result of meddling by third parties. Beijing is particularly irate over what it believes is intervention by Washington in recent years. According to one Chinese academic, speaking in 2011, "[T]he United States was more assertive in 2010, announcing a 'return to Asia,' and building up its military posture in the region." The academic contended that this growing U.S. assertiveness included ". . . increased civilian air and sea intelligence gathering efforts in the South China Sea."14

Another Shanghai-based analyst noted, "We think that Mrs. Clinton's remarks [in Hanoi in July 2010] are part of a plot by the US to get involved in an area and set of issues in which it doesn't belong." Exhibiting extreme suspicion of U.S. intentions, he argued, "China's disagreements with Vietnam, its disagreements over claims to the South China Sea ... have all existed for a long time. Why did they all come together . . . [in 2010]? I 
think external elements played a role, especially Mrs. Clinton's speech in Hanoi, which confused the issue of transit with the issue of sovereignty disputes and made the problems more serious." 15 The bottom line is that Beijing perceives Washington as threatening and views U.S. actions in the Asia-Pacific with considerable suspicion. ${ }^{16}$ It is too soon to tell what impact if any the Donald J. Trump administration will have on U.S.-China relations and U.S. policy toward the South China Sea. Under President Trump the climate of bilateral relations might improve, worsen, or perhaps not change at all.

\section{CONCLUSION}

The challenges of addressing the South China Sea disputes through peaceful negotiations are daunting. While the dangers of escalation may be less than those of other East Asian hot spots, the potential for escalation in the South China Sea may be growing because of the stability-instability paradox and an incipient regional arms race. The most powerful claimant has adopted a SLIC strategy and seeks to exclude third parties becoming involved. Some other states appear to welcome third-party involvement.

Under the circumstances, a four-step approach seems sensible: first, to de-escalate tensions; second, to identify appropriate third-party facilitators; third, to manage the disputes; fourth, to resolve the disputes.

\section{De-escalate Tensions}

There are a number of immediate measures disputants could use to de-escalate tensions, build trust, or at least limit the potential for further escalation. For example, all countries could cease construction of permanent structures and artificial islands. Moreover, disputants could agree to demilitarize the South China Sea and refrain from aggressive and dangerous actions. Thus, coastguards would be preferred over navies. Indeed, this is already occurring, as some countries are employing more white hulls. And coastguard vessels from all countries could be instructed not to engage in activities that would endanger human life or damage property.

\section{Designate Appropriate Third Parties to Serve as Mediators and Adjudicators}

As noted, China in particular is opposed to the involvement of third parties in these territorial disputes. This is in part because Beijing views 
some of the prominent third-party states involved, notably the United States, with great suspicion and does not perceive them as neutral actors. Thus, it is necessary to engage external states that would be viewed as impartial by all of the disputants. States such as Sweden or Canada might be appropriate candidates.

\section{Manage the Disputes with Third-Party Assistance}

Third-party states can help formulate rules of the road and/or establish enforcement mechanisms in the South China Sea. ${ }^{17}$ If recent history is any guide ASEAN may not be the most suitable venue in which to hammer out a code of conduct. ${ }^{18}$ A code of conduct should be approved by all disputants after being formulated either under the auspices of ASEAN or a neutral third party. One avenue worth pursuing is the establishment of a maritime nature park in a portion or portions of the South China Sea. Within the boundaries of the regional nature park no fishing, drilling or constructing of man-made structures would be permitted. A multilateral entity could be formed and charged with responsibility for monitoring and enforcing the sanctity of the maritime nature park. For such an enterprise to have a real chance of success all parties would need to be in agreement and third-party involvement would likely be required.

\section{Resolve the Disputes}

Building on step three, neutral third-party states could help nurture trust among the disputants and/or help to adjudicate the South China Sea dispute. If third parties were able to earn the respect of, and develop trust among disputants, then perhaps the disputants might be willing to commit to abide by a negotiated settlement. All parties would need to be willing to accept common principles and concepts. A logical way to turn is toward UNCLOS even though there are different interpretations of this UN convention. Even more difficult would be how to address the 2016 arbitral ruling in the China-Philippines case. It is extremely unlikely that China would be prepared to consider this legal judgment in any process or dialogue moving forward.

In sum, making progress on the South China Sea dispute will be extremely challenging. Building trust is vital but this will be difficult. The most promising way forward lies in making meaningful but incremental steps. And third-party involvement will likely be required if the slow boil in the South China Sea is to be abated. 


\section{NOTES}

1. This paragraph is drawn from Andrew J. Nathan and Andrew Scobell, China's Search for Security (New York: Columbia University Press, 2012).

2. Robert D. Kaplan, Asia's Cauldron: The South China Sea and the End of a Stable Pacific (New York: Random House, 2014).

3. Andrew Scobell, "An Orderly, Pacific Asia or Asia-Pacific Powder Keg?" Issues and Studies, Vol. 41, No. 1 (March 2005): 244-50.

4. Andrew T.H. Tan, The Arms Race in Asia: Trends, Causes, Implications (New York: Routledge, 2014). Geoffrey Till contends the region is experiencing a "slow motion arms race." See Geoffrey Till, Asia's Naval Expansion: An Arms Race in the Making? (London: International Institute for Strategic Studies, 2012), 35, 241.

5. The International Institute for Strategic Studies (IISS), The Military Balance 2013 (New York: Routledge, 2013), 250.

6. Paul Bracken, Fire in the East: The Rise of Asian Military Power and the Second Nuclear Age (New York: HarperCollins, 1999).

7. The three paragraphs in this section are drawn from Nathan and Scobell, China's Search for Security (New York: Columbia University Press, 2012).

8. Press Release of The South China Sea Arbitration (The Republic of the Philippines vs. The People's Republic of China, PCA Case No 2013-19, The Hague, the Netherlands: Permanent Court of Arbitration, July 12, 2016.

9. This paragraph and the five that follow are drawn from Nathan and Scobell, China's Search for Security.

10. See for example, Bill Hayton, The South China Sea: The Struggle for Power (New Haven: Yale University Press, 2014), 170, 264.

11. For analysis, see Hayton, The South China Sea, 125.

12. See, for example, Lyle J. Morris, "Blunt Defenders of Sovereignty: The Rise of Coast Guards in East and Southeast Asia," Naval War College Review, Vol. 70, No. 2 (2017): $75-112$.

13. See Andrew Scobell, "Slow Intensity Conflict in the South China Sea," E-Note (Philadelphia, PA: Foreign Policy Research Institute, distributed August 16, 2000) and Andrew Scobell, "China's Strategy toward the South China Sea," in Taiwan's Maritime Security, ed. Martin Edmonds and Michael M. Tsai (London: Routledge Curzon, 2003): 40-51.

14. Quoted in Andrew Scobell and Scott W. Harold, "An 'Assertive' China? Insights from Interviews," Asian Security, Vol. 9, No. 2 (2013): 119-20.

15. Quoted in Scobell and Harold, "An 'Assertive' China?", 120.

16. Andrew J. Nathan and Andrew Scobell, "China Sees America: The Sum of Beijing's Fears," Foreign Affairs, Vol. 91, No. 5 (2012): 32-47.

17. These mechanisms could be structured and function in any number of ways, including the use of clearly marked aircraft, sea craft, and use of satellite photography. It might be possible to draw on the lessons of multilateral cooperation in humanitarian search and rescue efforts such as the hunt for MH370.

18. For discussion of the role of ASEAN and the United States in recent efforts to deal with the South China Sea dispute, see Sheldon W. Simon, "Conflict and Diplomacy in the South China Sea: The View from Washington," Asian Survey, Vol. 52, No. 6 (2012): 995-1018. 